Підсумовуючи викладене вище, можна зробити висновок, що попередній та основний договори необхідно розглядати тільки у їхній єдності з точки зору тих наслідків, на які спрямовані інтереси суб'єктів цивільного та господарського права. В цьому розумінні попередній договір не $\epsilon$ самостійною угодою, а $\epsilon$ угодою, яка знаходиться у тісному взаємозв'язку з основним договором. Попередній договір при такому розумінні $є$ частиною переддоговірної стадії укладення основного договору. Визначення попереднього як організаційного дозволяє зробити висновок, що з попереднього договору не виникають певні майнові зобов'язання, однак виникає інший правовий наслідок пов'язаність контрагентів обов'язком укласти основний договір.

\title{
Література:
}

1. Клименко О.М. Попередній договір в цивільних відносинах: теорія і практика: автореф. дис. ... канд. юрид. наук: 12.00.03. Київ, 2010. $20 \mathrm{c}$.

2. Цивільний кодекс України: Закон України від 16.03.2003 р. №435-IV / Верховна Рада України. URL: https://zakon.rada.gov.ua/ laws/show/435-15\#Text (дата звернення 03.02.2021 p.).

3. Господарський кодекс України: Закон України від 16.01.2003 p. №436-IV / Верховна Рада України. URL: https://zakon.rada.gov.ua/ laws/show/436-15\#Text (дата звернення 03.02.2021р.).

DOI https://doi.org/10.30525/978-9934-26-040-7-23

\section{СКАСУВАННЯ РІШЕННЯ СУДУ ПРО ВИЗНАННЯ ФІЗИЧНОЇ ОСОБИ НЕДІЕЗДАТНОЮ}

\section{Татулич І. Ю.}

кандидат юридичних наук,

доцент кафедри процесуального права юридичного факультету

Чернівецького національного університету імені Юрія Федьковича м. Чернівиі, Украӥна

У зв'язку з внесеними змінами до процесуального законодавства (2017 р.) істотно зазнали змін справи, що стосуються зміни правового стану фізичної особи, а саме розгляд судом справ про обмеження 
цивільної дієздатності фізичної особи, визнання фізичної особи недієздатною та поновлення цивільної дієздатності фізичної особи (ст. 295-300 Цивільного процесуального кодексу України) (далі ЦПК України). Так, законодавець розширив коло суб'єктів участі в цьому виді провадження, передбачив можливість безпосередньої участі особи, щодо якої ініційовано провадження про визнання iï недієздатною, як очно, так і іï участь у розгляді справи через відеоконференцію з лікувального закладу, в якому перебуває така особа, встановив строки дії рішення суду про визнання фізичної особи недієздатною, який не може перевищувати двох років, надав право визначеним суб'єктам подати клопотання про продовження строку дії рішення про визнання фізичної особи недієздатною, яке може бути подане не пізніше ніж за п'ятнадцять днів до закінчення двох років тощо. Запроваджені новели слід вітати, оскільки вони є гарантією доступу до суду, узгоджуютьсязістаттею 6 Конвенціїззахисту прав i свобод людини, де вказано, що кожен має право на справедливий i публічний розгляд його справи [2]. Так, Свропейський суд із прав людини в рішенні зі справи Штукатуров проти Росії зазначає, що у низці розглянутих раніше справ Європейський Суд підтверджував, що душевнохворим має бути надано можливість бути вислуханим особисто або через ту чи іншу форму юридичного представництва [3].

Якщо стосовно організації підготовки та розгляду таких справ у нас не виникає жодних застережень, оскільки законодавець чітко визначає підсудність таких справ; вичерпне коло заявників, які вправі звернутися до суду; зміст заяви, яка крім загальних вимог, передбачених в ст. 175-177 ЦПК України, повинна відповідати спеціальним вимогам статті 297 ЦПК; процесуальні дії судді при підготовці таких справ до розгляду; колегіальний розгляд справ (в складі одного судді і двох присяжних), з дотриманням принципів гласності та відкритості, за участі суб'єктів, визначених в законі, з особливою процедурою ухвалення та реалізації судового рішення, то щодо скасування ухваленого рішення можуть виникати певні питання.

Заслуговує на увагу положення стосовно суб'єктів, які вправі звернутися до суду із заявою про скасування такого рішення, до яких відносяться опікун, члени сім’ї, орган опіки та піклування або сама особа, визнана недієздатною. У зв'язку з цим уточненню та з'ясуванню підлягають ряд питань, пов'язаних із процесуальним становищем особи, визнаної недієздатною, яка вправі звернутися до суду. На це питання, свого часу, звернув увагу Свропейський суд з прав людини у рішенні «Наталія Михайленко проти України» (справа № 49069/11) від 30 травня 2013 року, який визнав порушенням статті 6 Конвенції 
про захист прав людини і основоположних свобод відсутність доступу в Україні до процедури поновлення дієздатності недієздатної особи. Суд зазначив, що право звертатися з позовом про перегляд справи про дієздатність є одним із найважливіших прав людини і стосується процедур, важливих при реалізації всіх прав і свобод.

Так, ми не заперечуємо цього, адже дані зміни спрямовані на утвердження конституційного права на судовий захист. Однак, залишається відкритим питання, яким чином сама особа, визнана недієздатною зможе виступати суб'єктом порушення питання про поновлення іiі в дієздатності? Дана особа, в більшості випадків, може бути юридично необізнана, не володіти інформацією щодо своїх прав, обов'язків, та способів їх реалізації. Опікуни чи члени сім’ї часто зловживають своїми правами та обов'язками по відношенню до свого підопічного та не бажають ініціювати питання поновлення цивільної дієздатності фізичної особи. Органи опіки та піклування теж не завжди здатні захистити в суді права недієздатної особи, що в кінцевому рахунку може призвести до порушення конституційного права особи на судовий захист.

Звісно, ми визнаємо, що держава подбала про забезпечення правового захисту особи, що визнається недієздатною. Така особа має право отримати безоплатну правову допомогу в місцевому центрі 3 надання безоплатної вторинної правової допомоги протягом розгляду іiі справи в суді. Однак, особа може не мати можливості звернутися до адвоката для того, щоб укласти з адвокатом договір про надання правової допомоги чи звернутися до центру надання безоплатної вторинної правової допомоги тощо.

Звідси, заслуговує на увагу думка М. Ю. Мерцалова, який вбачає у даних категоріях справ обов'язкову участь адвоката. Так, упровадження обов'язковості участі адвоката в цьому виді окремого провадження стало б більш ефективним засобом забезпечення захисту прав та свобод цієї категорії осіб та засобом належної правової допомоги. Існування обов'язковості участі адвоката в процесі поновлення цивільної дієздатності гарантувало б отримання недієздатними особами професійної правової допомоги [4, с. 54-55]. Дане питання було об’єктом уваги і в Ю. О. Підченка, який вважає, що фізичні особи, які були визнані недієздатними за рішенням суду наділяються нульовою цивільною процесуальною дієздатністю, що полягає у здатності через представника здійснювати у суді цивільні процесуальні права i виконувати цивільні процесуальні обов'язки певного учасника цивільного процесу. Таким чином, у справах про скасування рішення суду про визнання фізичної особи недієздатною та поновлення цивільної 98 
дієздатності фізичної особи, яка була визнана недієздатною, заявником, поряд 3 опікуном, членами сім’і такої особи, органу опіки та піклування, може виступати сама особа, визнана недієздатною, проте здійснювати в суді свої цивільні процесуальні права та виконувати свої цивільні процесуальні обов'язки вона управомочена тільки через законного представника - опікуна [5, с. 122]. Крім того, відповідно до частини 3 статті 10, частини 3 статті 18 Закону України «Про безоплатну правову допомогу», звернення щодо отримання безоплатної первинної та вторинної правової допомоги стосовно недієздатної особи може бути подано лише його опікуном [6].

Таким чином, безпосередне звернення особи, яка була визнана недієздатною до суду, ставить під сумнів ефективний розгляд та вирішення даних справ. На жаль, діючий ЦПК на відміну від ЦПК 1963 р. (ч.1 ст. 256) не передбачає серед кола суб'єктів у даних справах прокурора, який міг бути заявником. Однак, на наш погляд, розглядаючи питання скасування рішення суду про визнання фізичної особи недієздатною, розширення потребує перелік заявників, уповноважених на звернення до суду, зокрема, передбачити право прокурора на подання такої заяви. Тим паче, що подібний підхід щодо обов'язкової участі у розгляді справи прокурора законодавець застосував при розгляді заяви про надання особі психіатричної допомоги у примусовому порядку (ст. 341 ЦПК), що на думку як науковців, так i практиків $\epsilon$ цілком виправданим. Безумовно, не потребує доказування той факт, що відповідно до Конституції України, а саме п. 3 ст. 131-1 прокурор здійснюе представництво інтересів держави в суді у виключних випадках і в порядку, що визначені законом. Однак, відповідно до ст. 23 Закону України «Про прокуратуру» представництво прокурором інтересів громадянина або держави в суді полягає у здійсненні процесуальних та інших дій, спрямованих на захист інтересів громадянина або держави, у випадках та порядку, встановлених законом. Прокурор здійснює представництво в суді інтересів громадянина (громадянина України, іноземця або особи без громадянства) у випадках, якщо така особа не спроможна самостійно захистити свої порушені чи оспорювані права або реалізувати процесуальні повноваження через недосягнення повноліття, недієздатність або обмежену дієздатність, а законні представники або органи, яким законом надано право захищати права, свободи та інтереси такої особи, не здійснюють або неналежним чином здійснюють іiі захист [7]. ЦПК України також дозволяє участь у цивільному процесі органів та осіб, яким законом надано право захищати права, свободи та інтереси інших осіб (ст. 56-57 ЦПК). Іншими словами, складність та 
актуальність зазначених вище питань дають підстави стверджувати про необхідність залучення до вирішення таких питань прокурора.

Загалом, зі змінами до ЦПК України особи, щодо яких розглядаються справи стосовно визнання недієздатними, отримали значно ширші права, в порівнянні $з$ попередньою редакцією Кодексу, що свідчить про позитивні зрушення у сфері дотримання громадянських прав, проте формує підгрунтя для подальших змін та досягнень у сфері правосуддя та в процесуальному законодавстві.

\section{Література:}

1. Цивільний процесуальний кодекс України : чинне законодавство зі змінами та допов. станом на 1 верес. 2020 р. : (офіц. текст). К.: Паливода А. В., 2020. 304 с.

2. Конвенція про захист прав людини і основоположних свобод від 04.11.1950 року зі змінами та доповненнями станом на 02.10.2013 p. URL: http://zakon3.rada.gov.ua/laws/show/995_004.

3. Рішення Європейського суду з прав людини «Штукатуров проти Росії» від 27.03.2008 p. URL: http://hudoc.echr.coe.int/ eng?i=001-85611.

4. Мерцалов М. Ю. Участь адвоката в окремому провадженні щодо визнання фізичної особи недієздатною. Актуальні проблеми вітчизняної юриспрудениії. 2019. С. 53-56.

5. Підченко Ю. О. Судові рішення у справах окремого провадження : дис. ...канд. юрид. наук : 12.00 .03 / Ю. О. Підченко. К., 2019. $206 \mathrm{c}$.

6. Закон України «Про безоплатну правову допомогу»: Закон України від 02.06.2011 № 3460-VI зі змінами та доповненнями станом на 04.11.2018. URL: http://zakon2.rada.gov.ua/laws/show/3460-17.

7. Закон України «Про прокуратуру» від 14 жовт. 2014 p. Відомості Верховної Ради України. 2015. № 2-3. Ст. 12. 